\title{
症例報告
}

$$
\begin{aligned}
& \text { 急性期に無症候性心筋梗塞を合併した川崎病冠動脈瘤の乳児例 } \\
& \text { 並木 秀匡 }{ }^{1)} \text { 鮎澤 } \text { 衛 }^{1)} \text { 小森 暁子 }{ }^{1)} \text { 山瀬 聡一 }{ }^{1)} \\
& \text { 渡邊 未央 }{ }^{1)} \text { 石井 大裕 }{ }^{1)} \text { 野崎 千央 }{ }^{1)} \text { 藤澤 惊平 }{ }^{1)} \\
& \text { 飯田亜希子 }{ }^{1)} \text { 加藤 雅崇 }{ }^{1)} \text { 神保 詩乃 }{ }^{1)} \text { 中村 隆広 }{ }^{1)} \\
& \text { 神山浩 }{ }^{1,2} \text { 森岡 一朗 }{ }^{1)} \\
& \text { 1) 日本大学医学部小児科学系小児科学分野 } \\
& { }^{2)} \text { 日本大学医学部 IR ・医学教育センター }
\end{aligned}
$$

\section{Acute Asymptomatic Myocardial Infarction Complicating Kawasaki Disease in an Infant: A Case Report}

\author{
Hidemasa Namiki $^{1)}$, Mamoru Ayusawa ${ }^{1)}$, Akiko Komori ${ }^{1)}$, Souichi Yamase ${ }^{1)}$,

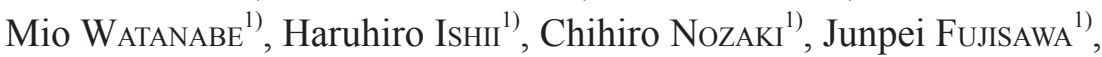 \\ Akiko IIDA $^{1)}$, Masataka Kato ${ }^{1)}$, Shino JimBo ${ }^{1)}$, Takahiro NAKAmURA ${ }^{1)}$, \\ Hiroshi KAMIYAMA ${ }^{1,2)}$, and Ichiro MORIOKA ${ }^{1)}$ \\ ${ }^{1)}$ Department of Pediatrics and Child Health, Nihon University School of Medicine \\ ${ }^{2)}$ Center for Institutional Research and Medical Education, Nihon University School of Medicine
}

\begin{abstract}
A 5-month-old male infant was diagnosed with Kawasaki disease on the 4th day of disease onset. He was treated with intravenous immunoglobulin, oral aspirin, and prednisolone. However, owing to dilatation of his coronary arteries on the 18th day of illness, he was transferred to our hospital. Echocardiography revealed bilateral coronary artery aneurysms; however, no intraluminal thrombus was identified. Anticoagulation therapy with heparin was initiated after confirming these findings. Based on electrocardiographic changes and elevated serum levels of biomarkers of myocardial injury, he was diagnosed with acute myocardial infarction on the 20th day of illness. Intravenous or intracoronary thrombolysis was not performed because he was asymptomatic, and increasing heparin administration was expected to improve reperfusion. Sudden death can occur in patients with myocardial infarction complicating Kawasaki disease. Therefore, the indications for acute thrombolytic therapy should be carefully determined based on its need and safety.
\end{abstract}

Key words: Kawasaki disease, Myocardial infarction, coronary aneurism, Anti-thrombus therapy, Anticoagulant therapy

川崎病, 心筋梗塞, 冠動脈瘤, 抗血栓療法, 抗凝固療法

(J. Nihon Univ. Med. Ass., 2019; 78 (2): 111-116)

\begin{abstract}
要旨 川崎病急性期の心筋梗塞の報告は近年少ない. 症例は 5 か月男児．前医で川崎病と診断し治療後，第 18 病日に冠動脈瘤を認め当院に転院後, ヘパリンによ る抗凝固療法を開始し無症状であったが，第 20 病日に 心電図変化により急性心筋梗塞の合併を診断した。心臓 超音波法で瘤内血栓なく, 経口抗凝固療法によって管理 した，無症状だが突然死の可能性もあり，血栓溶解療法 について必要性と安全性を十分勘案し適応決定する必要 がある。
\end{abstract}

\section{はじめに}

川崎病は 1967 年に初めて報告され，当初は予後良好
な疾患と考えられていたが ${ }^{1)}$, 間もなく 1970 年代以降, 冠動脈瘤を合併して血栓性閉塞により心筋梗塞を発症 して死亡する例があることがわかり急速に注目される 疾患となった。1983 年の心臓血管後遺症の発生頻度は $16.7 \%$ と多く, 致命率も $2 \%$ 程度と高かった ${ }^{2}$. 現在, アスピリンと免疫グロブリン大量療法が標準的な治療法 として行われ, 川崎病の後遺症としての冠動脈瘤の合併 は $1.9 \%$ と少なくなり，1990 年代からは冠動脈瘤を合併 した例であっても，抗凝固療法としてワルファリンの小 児での使用が普及し，急性心筋梗塞の合併は $0.02 \%$ と 非常にまれとなった ${ }^{3)}$ 。また，心筋梗塞は川崎病発症後 1 年以内に合併することが $72.8 \%$ と多いが，発症 1 か月 
以内に起こるのは $17 \%$ 程度と報告される ${ }^{4)}$. 今回, 発症 1 か月以内に急性心筋梗塞をきたした 5 か月男児を経験 した。きわめて症状に乏しく，無症候性心筋梗塞と言え る経過であり，その原因と治療について考察したので報 告する。

\section{症例}

\section{5 か月男児}

主訴：発熱, 哺乳低下

現病歴：発熱, 哺乳低下あり前医を受診, 急性上気道炎 の診断で入院した。第 4 病日に眼球結膜の充血, 口唇の 発赤, 澒部リンパ節の腫脹, 皮疹, 手指の硬性浮腫と足 底の発赤を認め, 川崎病主要症状 $6 / 6$ 項目を満たし川崎 病と診断された。群馬スコア 5 点と免疫グロブリン不応 予測例であり，同日より免疫グロブリン $2 \mathrm{~g} / \mathrm{kg} /$ 回，プレ ドニゾロン (PSL) $2 \mathrm{mg} / \mathrm{kg} /$ 日，アスピリン (ASA) $40 \mathrm{mg} /$ $\mathrm{kg} /$ 日を投与された。治療後は速やかに解熱し，川崎病 の主要症状の再燃もなかったが，第 18 病日の血液検査 で炎症反応の再上昇と心臓超音波検査で冠動脈の拡張が 認められ，精査加療目的に当院に搬送された。

既往歴：特記すべきことなし。

家族歴：川崎病の家族歴なし。

入院時現症：身長 $66.4 \mathrm{~cm}$, 体重 $6.9 \mathrm{~kg}$, 体温 $36.3^{\circ} \mathrm{C}$, 心拍数 105 回/分, 血圧 92/46 mmHg. 眼球結膜充血なし, 口唇発赤あり，イチゴ舌なし，頝部リンパ節腫脹なし， 呼吸音清, 心雑音なし, 心音整, 腹部平坦 ·軟, 腸蠕動 音正常。手掌紅斑あり，硬性浮腫なし，皮疹なし，

入院後経過：当院転院時, 12 誘導心電図で $\mathrm{ST}$ 変化や異 常 $\mathrm{Q}$ 波などの異常は認めなかった。 心臓超音波検査で
左冠動脈主幹部 $3.3 \mathrm{~mm}$ （ $\mathrm{Z}$ スコア 4.9 : 以下 $\mathrm{Z}=$ 数值と 表記 $)$, 前下行枝 $4.8 \mathrm{~mm}(Z=6.7)$, 回旋枝 $3.3 \mathrm{~mm}(Z=$ 4.6), 右冠動脈 $4.3 \mathrm{~mm}(Z=7.3)$ に冠動脈瘤を認めた (Fig. 1: 第 18 病日). 免疫グロブリン $2 \mathrm{~g} / \mathrm{kg}$ /回を再投与 し，PSL $2 \mathrm{mg} / \mathrm{kg} /$ 日，ASA $40 \mathrm{mg} / \mathrm{kg}$ /日を継続した (Fig. 2)，血圧変動による冠動脈の更なる拡張を懸念し，予防 目的にプロプラノロール $2 \mathrm{mg} / \mathrm{kg} /$ 日の内服を開始した。 血栓予防目的に抗凝固療法にへパリン 15 単位 $/ \mathrm{kg} /$ 時を開 始し適宜増量した。第 20 病日に血液検査で CK 579 U/1, AST 202 U/1, ALT 33 U/1, LDH 660 U/1 と心筋逸脱酵素 の上昇を認めたため，12 誘導心電図を施行したところ，

II，III，aVF と V1-5のST 上昇を認めた（Fig. 3: 第 20 病日)。血圧は保たれており，心臓超音波検査で前壁中 隔の浮腫と輝度上昇を認めたが，瘤内血栓や明らかな 局所壁運動低下は認めなかった (Fig. 4)。急性心筋梗塞 を疑い, ヘパリンを 30 単位 $/ \mathrm{kg} /$ 時に増量し, ワルファ リンを初回量として $0.2 \mathrm{mg} / \mathrm{kg} /$ 日追加した。無症状であ り，同日 6 時間後に再検した血液検査で CK 284 U/1, AST 143 U/1, ALT 32 U/1, LDH 619 U/1, トロポニン T と心筋逸脱酵素はピークアウトしており，以後も Fig. 3 のように4 日後までに正常化した。治療としては，ステ ロイドが凝固能を立進させている可能性を考え, PSLの 漸減を開始し，同時に心臓超音波検査で瘤内血栓を認め なかったことから，血栓溶解療法は施行しない方針とし た。無症状であり，同日 6 時間後に再検した血液検査で CK 284 U/1, AST 143 U/1, ALT 32 U/1, LDH 619 U/1, ト ロポニン $\mathrm{T}$ と心筋逸脱酵素はピークアウトしており， 以後も Fig. 3 のように 4 日後までに正常化した。治療と しては, PSLを $1.5 \mathrm{mg} / \mathrm{kg} /$ 日に減量し, シクロスポリン
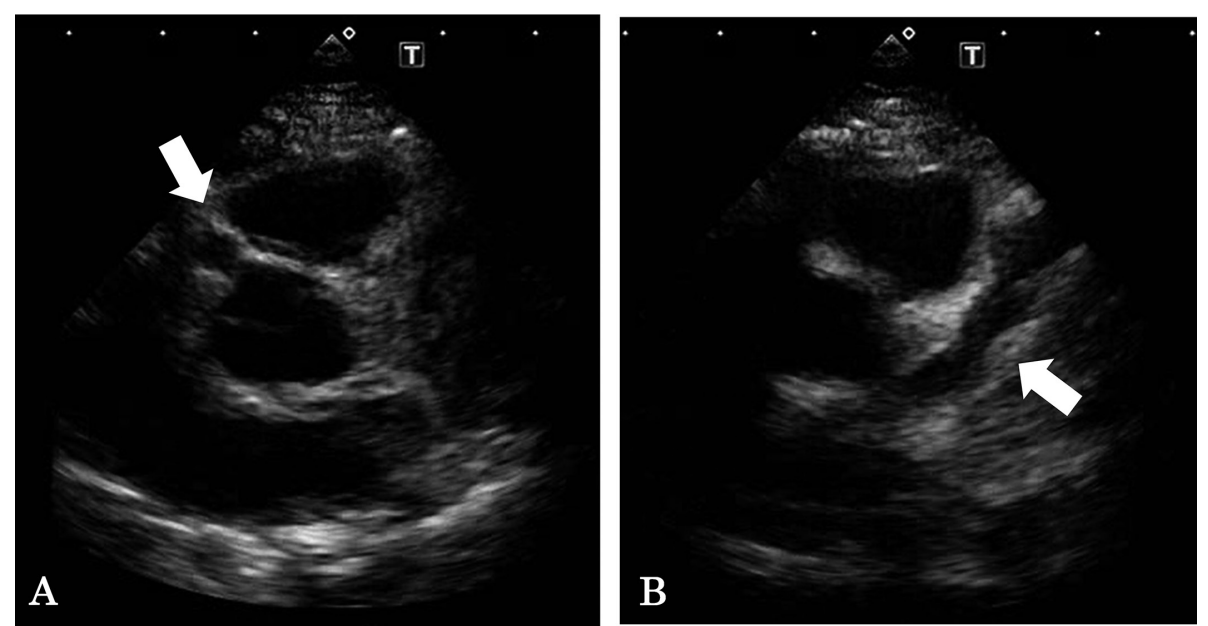

Fig. 1 Echocardiographic images show aneurysmal changes in both, the right and the left coronary arteries on the 18th day of the illness when the patient was transferred to our hospital A: The right coronary artery measures $4.3 \mathrm{~mm}$ in diameter (z score 7.3 ).

B: The left coronary artery at the main trunk measures $3.3 \mathrm{~mm}$ in diameter (z score 4.9$)$.

The left anterior descending coronary artery measures $4.8 \mathrm{~mm}$ in diameter ( $\mathrm{z}$ score 6.7).

The left circumflex coronary artery measures $3.3 \mathrm{~mm}$ in diameter (z score 4.6). 


\begin{tabular}{|c|c|c|c|c|c|c|c|c|c|}
\hline & day18 & day20 & $\begin{array}{l}\text { Day20 } \\
\text { (6hr後) }\end{array}$ & day21 & day22 & day23 & Day30 & $\begin{array}{c}\text { Day37 } \\
\text { (退院前) }\end{array}$ & Day63 \\
\hline WBC (/ul) & 16800 & 15500 & 11800 & 14500 & 14000 & 12900 & 9400 & 7900 & 11800 \\
\hline 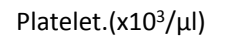 & 870 & 896 & & 897 & 924 & 538 & 503 & 497 & 439 \\
\hline Fibrinogen (mg/dl) & 347 & & & 232 & 227 & 198 & & 178 & \\
\hline AST (U/I) & 38 & 202 & 143 & 94 & 60 & 50 & 41 & 39 & 52 \\
\hline $\operatorname{ALT}(\mathrm{U} / \mathrm{I})$ & 21 & 33 & 32 & 31 & 28 & 28 & 17 & 21 & 20 \\
\hline LDH (U/I) & 206 & 660 & 619 & 535 & 368 & & 237 & 227 & 313 \\
\hline CK (U/I) & 10 & 579 & 284 & 124 & 59 & 42 & 32 & 31 & 197 \\
\hline CK-MB (U/I) & & & 63 & 22 & 9 & 9 & & & \\
\hline Troponin-I (ng/ml) & & & 20.15 & 15.72 & 7.36 & & & 0.04 & \\
\hline $\mathrm{CRP}(\mathrm{mg} / \mathrm{dl})$ & 1.57 & 0.32 & & 0.19 & 0.10 & 0.10 & 0.10 & 0.26 & 0.10 \\
\hline NTproBNP (pg/ml) & 188 & & & 1836 & & 3221 & 4584 & 2130 & 913 \\
\hline
\end{tabular}

PSL $2 \mathrm{mg} / \mathrm{kg} /$ day $\rightarrow \quad 1.5 \quad \rightarrow \quad 1.0 \quad \rightarrow 0.5 \rightarrow$ off

Heparin $15 \rightarrow 30 \mathrm{u} / \mathrm{kg} / \mathrm{hr}$

CyA $4 \mathrm{mg} / \mathrm{kg} /$ day

Warfarin $\quad 0.1 \mathrm{mg} / \mathrm{kg}$ (target INR $-2.5 \sim 3.0)$

Fig. 2 Laboratory data and treatment administered to the patient

CK: creatine kinase, CRP: C-reactive protein, CyA: cyclosporine A, IVIG: intravenous immunoglobulin, PSL: prednisolone.

18 th day 20 th day 37 th day 63 th day
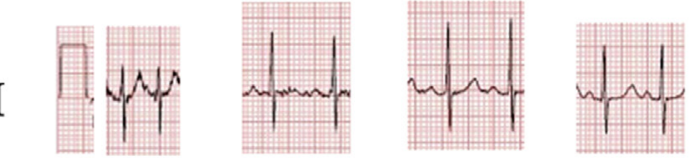

II
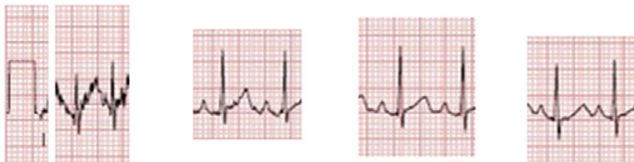

V2<smiles>N#N</smiles>

2
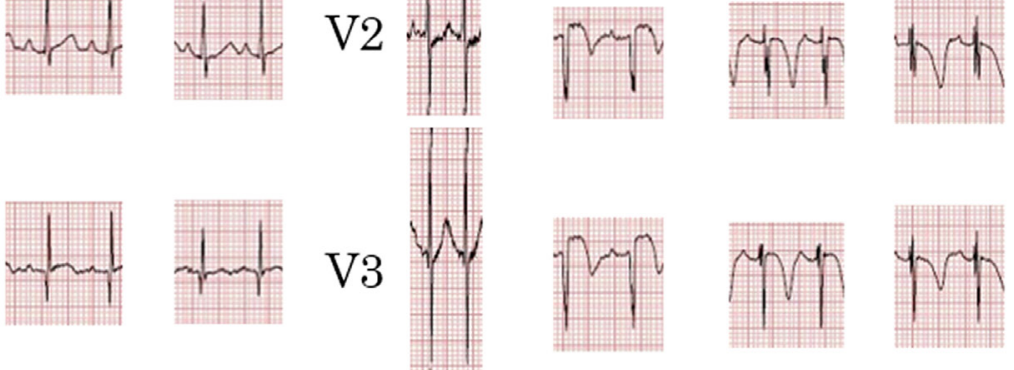

aVR 回
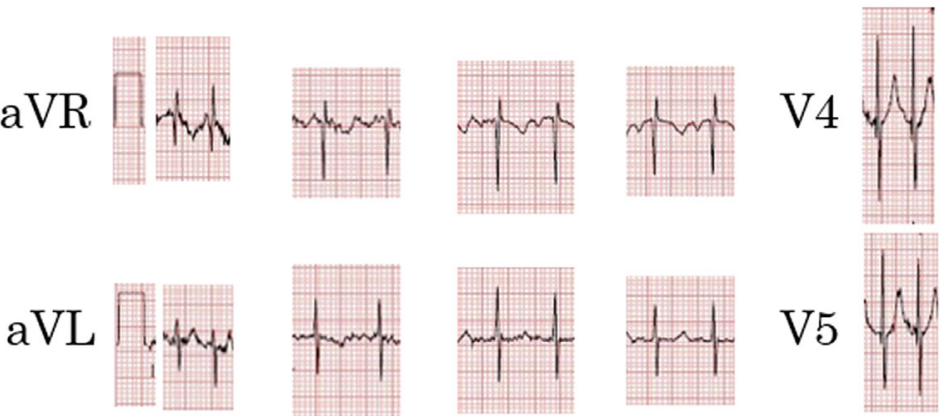

V5
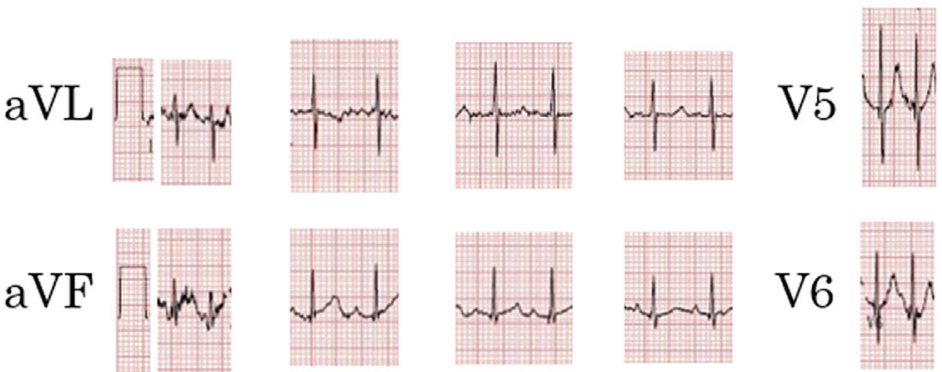

V6
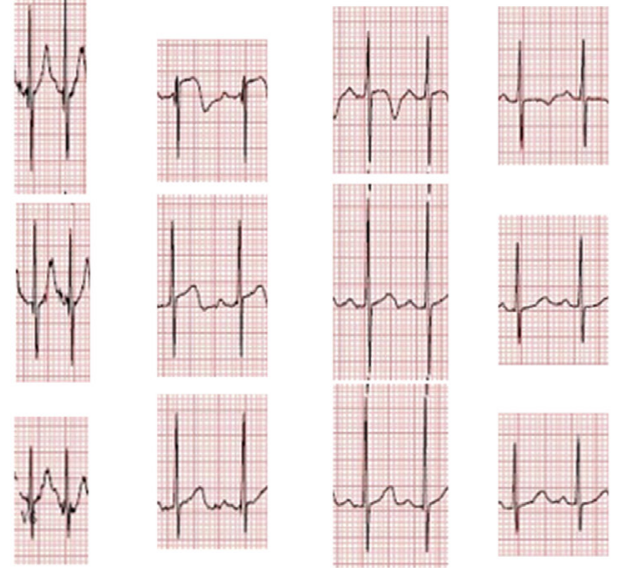

Fig. 3 Image shows electrocardiographic changes

Abnormal elevation of the ST segment is observed in leads II, III, aVF, and V1 to V5 on the 20th day of illness. Notably, the patient showed sudden elevations in serum levels of biomarkers of myocardial injury including CK, AST, and LDH.

AST: aspartate aminotransferase, CK: creatine kinase, LDH: lactate dehydrogenase. 

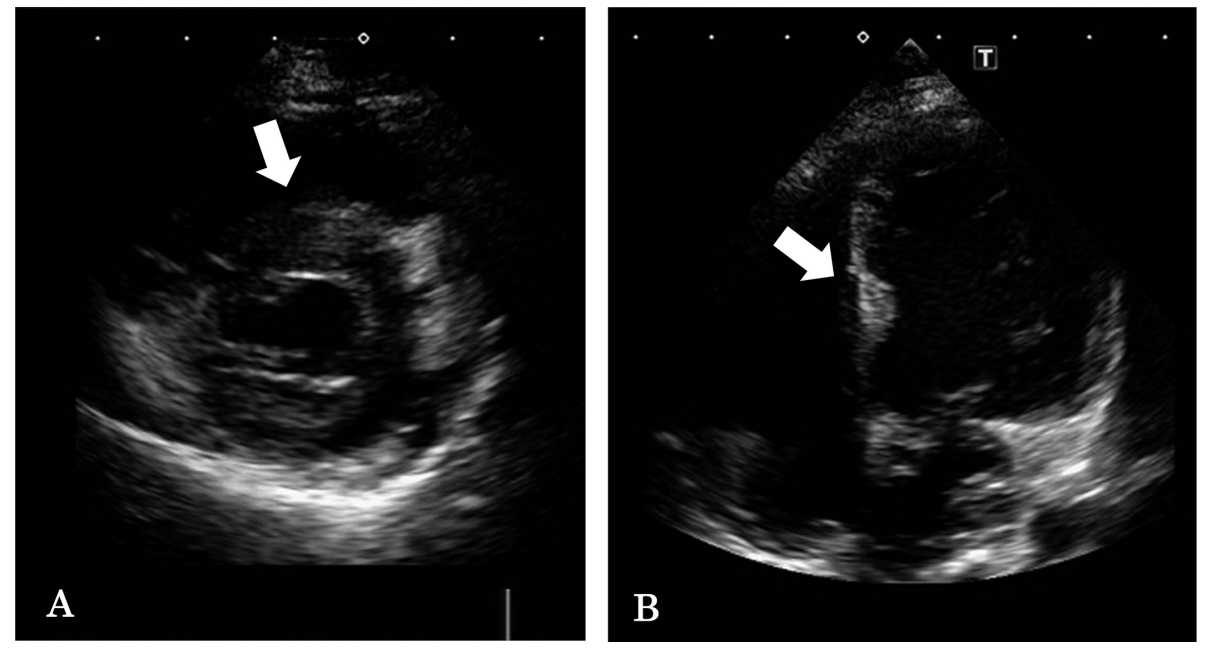

Fig. 4 Echocardiographic images obtained on the 20th day of illness

A: Left ventricle short axis view: The left ventricular anteroseptal wall is edematous with enhanced brightness. B: Left ventricle 4-chamber view: The ventricular septum is observed to be partially thickened and hypokinetic.
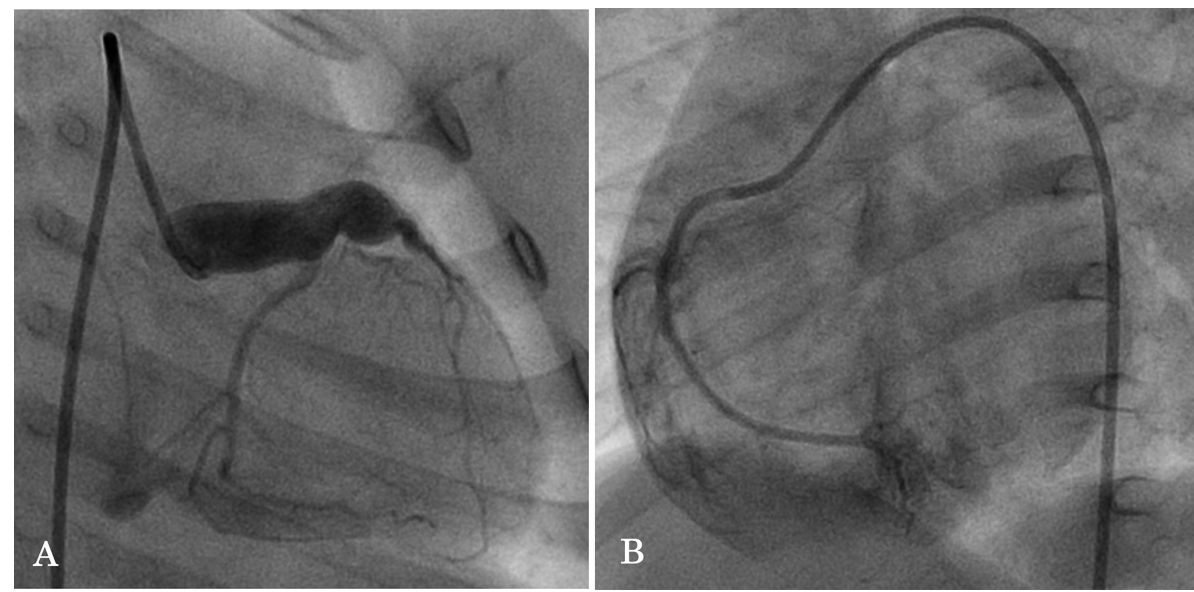

Fig. 5 Selective coronary angiographic images show:

A: RAO $30^{\circ}$ caudal $20^{\circ}$ view of the left coronary artery: Two aneurysms of the left coronary artery can be observed measuring $6.24 \mathrm{~mm}$ (z score 8.2$)$ and $6.48 \mathrm{~mm}$ (z score 8.4) in diameter.

B: LAO $40^{\circ}$ cranial $0^{\circ}$ view of the right coronary artery.

LAO: left anterior oblique projection, RAO: right anterior oblique projection.

$4 \mathrm{mg} / \mathrm{kg} /$ 日を併用した。収縮期血圧 $100 \mathrm{mg}$ 前後と高め であり, カンデサルタン $0.06 \mathrm{mg} / \mathrm{kg} /$ 日の内服を開始し た。また，同日から硝酸イソソルビド $1 \mathrm{mg} / \mathrm{kg} /$ 日を追加 投与した。 その後, プロトロンビン時間国際標準比は 2.5 3.0 を, 部分活性化トロンボプラスチン時間比は 2.0 前後を目標に適宜ワルファリンとへパリンを調整した。 ワルファリンによる抗凝固が十分であると判断し，第 26 病日にヘパリンを終了した。第 27 病日にシクロスポ リンとカンデサルタンを終了し, PSL $1 \mathrm{mg} / \mathrm{kg} /$ 日に減量 した。第 34 病日から PSL $0.5 \mathrm{mg} / \mathrm{kg} /$ 日に減量し 5 日間で 終了し，第 39 病日に退院した。最大瘤径は左冠動脈主 幹部で $4.3 \mathrm{~mm}(\mathrm{Z}=7.8)$, 前下行枝で $7.5 \mathrm{~mm}(Z=9.2)$, 回旋枝は $5.1 \mathrm{~mm}(\mathrm{Z}=6.8)$ であった。
発症 2 か月後に施行した冠動脈造影検査では左冠動脈 前下行枝にそれぞれ $6.24 \mathrm{~mm}(\mathrm{Z}=8.2)$ と $6.48 \mathrm{~mm}(\mathrm{Z}=8.4)$ の 2 つの中等冠動脈瘤を認めた (Fig. $5 \mathrm{~A})$. 一方で，右冠 動脈の退縮を認めた (Fig. 5B)。また，冠動脈㢚内の血流 うっ滞, 前下行枝の血流減少を認め, 心電図変化があっ た部位に一致していた。川崎病発症 3 か月後に施行した 安静時心筋血流イメージング (Tc99m-tetrofosmin) では明 らかな取り込み低下は認めなかったが，前壁中隔の一部 に血流再分布の可能性が示唆された。この時期までに, 心電図は徐々に胸部誘導 $\mathrm{R}$ 波と左側胸部誘導の $\mathrm{T}$ 波の 増高が見られてきている（Fig. 3: 第 37 病日，第 63 病 日)。

現在, 川崎病発症から 5 か月を経過しているがワルファ 

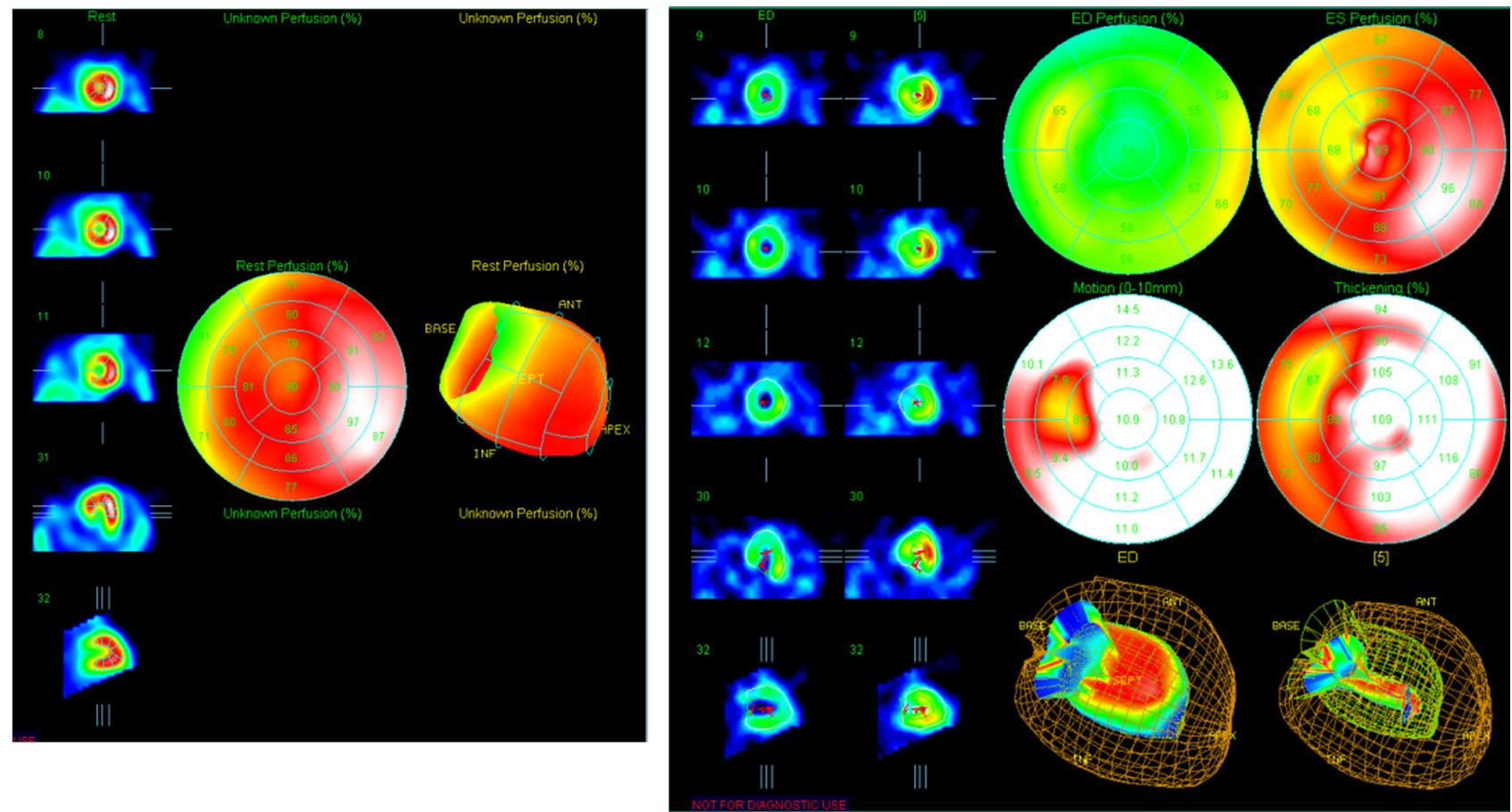

Fig. 6 Images show myocardial scintigraphy performed using Tc99m-tetrofosmin

No clear myocardial perfusion defect is observed; however, the possibility of reperfusion of the anteroseptal area cannot be ruled out.

リンによるコントロールは良好であり，心電図，心臓超 音波検査所見の悪化は認めていない.

\section{考 察}

本症例では免疫グロブリン抵抗が予測される重症川崎 病と診断し，免疫グロブリン・ステロイド初期併用療法 により治療を行った。治療により速やかに川崎病症状は 消失し， $36^{\circ} \mathrm{C}$ 台で解熱を維持していたが， PSL 減量前の 血液検査で炎症反応の再上昇があり，心臓超音波検査で 冠動脈瘤の合併を認めた。PSL 併用例では解熱を維持し ていても炎症が持続している症例があり，症状再燃がな くとも血液検査の再検により病勢を判断し，追加治療を 検討する必要があると考えられた。また，冠動脈瘤が形 成される頃に，本例では炎症をさらに鎮静化させるた めにIVIG を追加投与し血液の粘稠度が上昇した可能性 と，血小板の増多する時期であったことがへパリンと ASA 投与中にも関わらず，血栓を形成し心筋梗塞を発 症した原因であった可能性が考えられる。

心電図変化から左室前壁から中隔側にかけての心筋梗 塞を発症したにもかかわらず，壁運動異常や致死性の不 整脈を認めていなかったのは，トロポニン I 他のマーカー が 6 時間後の検査以降改善し，その後の心筋 SPECT か ら見て比較的早い時間でヘパリン増量により再灌流が得 られたためではないかと考える。

中等以上の冠動脈瘤形成例では心臓カテーテル検査に よる評価が望ましく，本症例でも施行した。退院前の第
37 病日に施行した心臓超音波検査で右冠動脈は $1.7 \mathrm{~mm}$ $(Z=1.1)$ とすでに縮小しており, 心藏カテーテル検査で 退縮を確認した。瘤の大きさと形態が急性心筋梗塞の発 症や逆に瘤の退縮や正常化に関与するとされ ${ }^{5)}$, 右冠動 脈病変は造影でも退縮が確認されたが, 退縮は内膜肥厚 による見かけ上の内腔正常化の可能性も考えられ, 今後, 狭窄性病変の可能性について長期的なフォローが必要で ある。

一方で，左冠動脈には数珠状に拡張した冠動脈瘤と冠 動脈瘤内の血流評価を行い, 心臓超音波検査や心電図で 変化を来した部位に一致して, 冠動脈瘤内の血流うっ滞 と前下行枝の血流減少を確認することが可能であった。

本症例では冠動脈造影で瘤内の血流うつ滞を認めた が，安静時心筋血流イメージング (Fig. 6) では，心筋へ の取り込み低下は明らかではなかった。その要因として は, 安静時のみの評価である点, 発症後 3 か月の回復期 評価であり，生存心筋を示唆している所見と考えられる. Bull’s eye 表示では，ごくわずかに前壁中隔領域に灌流 低下があったのち回復した可能性が示唆される。撮像時 期が発症後 3 か月目であり, 厳密には発症時に同検査を 施行できていれば明確になったかもしれない。また，薬 物や運動負荷を行えば血流低下を認める可能性があり, 今後も冠動脈狭窄により心筋虚血を起こす可能性はあ り, 定期的な評価が必要と考える。筋逸脱酵素は, 再 検時すでにピークアウトしており，短時間で再開通し心 筋障害の範囲と程度は軽度であったと考えられ，心蔵超 
音波検査でも瘤内血栓を認めなかったことから血栓溶解 療法は施行しなかった。

また本例では冠動脈造影時には誘発試験は行わなかっ たものの, カテーテル挿入時の血行動態は安定してお り，この時点では冠攣縮が発症しやすいとは考えにくかっ た。しかし，今後の日常生活での種々の刺激により，虚 血が冠攣縮性に起こる可能性もあると考え, 治療として 抗凝固療法の他に亜硝酸薬を使用している.

近年，急性期治療が奏効し心血管後遺症を合併する症 例が減少し，心筋梗塞の発症は非常に稀となった。筋 梗塞の急性期治療は施設設備と患者の状態によって再灌 流療法や経皮的冠動脈インターベンションが選択され $る^{6)}$. 再灌流療法には, 経静脈的血栓溶解療法, 冠動脈 血栓溶解療法 (intracoronary thrombolysis: ICT, percutaneous transluminal coronary revascularization: PTCR), 経皮 的冠動脈形成術 (percutaneous transluminal coronary angioplasty: PTCA) がある。血栓溶解療法において静脈内投 与と比較し冠動脈内投与の方が再開通率が高いと言われ ているが，乳児例では必要性と安全性を十分勘案して適 応を決定する必要がある。治療開始までの時間が短い方 がより効果的とされるため，薬剤投与に時間がかかる場 合は静脈内投与を施行する方が良いとされる。副作用と しては出血性合併症があり，成人例では約 $1 \%$ に脳出 血を合併するとされており慎重に適応を判断する必要が ある。また，再開通が得られない場合は PTCA が有効 な場合がある。すでに再開通していると判断した本症例 では再灌流療法の適応にならないと考えた。

川崎病の急性心筋梗塞では, 当然, 緊急的に症状発現 することもあり，乳児では非特異的な症状を呈すること がある7)。本症例では血液検査で心筋逸脱酵素の上昇 を認めたため心筋梗塞の発症に気付いたが，詳しく前夜 の様子を聞くと，前日夜間に異常な啼泣があった様で あった。確実な因果関係は明らかではなく，患者側から の主訴としての話ではないので, 医療者側に感知できる 症状とは考えずに，ここでは今後への注意も含めて，無
症候性心筋梗塞として述べた。川崎病の急性期には心筋 梗塞のリスクがある患者と家族には泣き声の変化など非 特異的な症状についても気になれば報告するように説明 し, 慎重に症状観察, 検査, 評価に努める必要がある.

\section{謝辞}

本論文の一部は, (公財) 川野小児医学奨学財団およ び日本医療研究開発機構の助成によって行われた。

\section{COI (Conflicts of interest) 開示}

並木秀匡, 小森暁子, 山瀬聡一, 渡邊未央, 石井裕大, 野崎千央, 藤澤淳平, 飯田亜希子, 加藤雅崇, 中村隆 広，神保詩乃，神山浩：上全て開示すべき COI：なし， 鮎沢 衛; 講演料 (帝人ファーマ, 日本血液製剤機構), 森岡一朗; 講演料 (MSD), 研究費・助成金（アトムメディ カル株式会社, アッヴィ合同会社)

\section{文献}

1）川崎富作．指趾の特異的落屑を伴う小児の急性熱性皮膚 粘膜淋巴腺症候群 (自験例 50 例の臨床的観察)。アレル ギー 1967; 16: 178-222.

2) Nakamura $Y$, Yashiro M, Uehara R, et al. Epidemiologic features of Kawasaki disease in Japan: results of the 2009-2010 nationwide survey. J Epidemiol 2012; 22: 216-221.

3) Suda K, Kudo Y, Higaki T, et al. Multicenter and retrospective case study of warfarin and aspirin combination therapy in patients with giant coronary aneurysms caused by Kawasaki disease. Circ J 2009; 73(7): 1319-1323.

4) Kato H, Ichinose E, Kawasaki T. Myocardial infarction in Kawasaki disease: Clinical analyses in 195 cases. J Pediatr 1986; 108: 923-927.

5) Nakano H, Ueda K, Saito A. Repeated quantitative angiograms in coronary arterial aneurysm in Kawasaki disease. $\mathrm{Am}$ J Cardiol 1986; 56(13): 846-851.

6）田中秀造，山本雅史，藤本善英，他．左主幹部冠動脈瘤 の閉塞により急性心筋梗塞を発症した川崎病既往の小览 例。心臓 2008; 40(7): 642-646.

7）津田悦子，高室基樹，遠藤彦聖，他．川崎病による冠動 脈閉塞に伴う症状の出現頻度について. Prog Med 2000; 2 404-405. 